\title{
NUMERICAL SIMULATION OF HEAT TRANSFER IN A CANINE KNEE JOINT IN THERMAL NEUTRALITY: ANALYSIS OF THE INFLUENCE OF DIFFERENT VALUES OF BLOOD PERFUSION AND CONSIDERATIONS OF THE BLOOD PERFUSION RATE
}

\author{
SIMULAÇÃO NUMÉRICA DA TRANSFERÊNCIA DE CALOR NA ARTICULAÇÃO \\ DO JOELHO CANINO EM NEUTRALIDADE TÉRMICA: ANÁLISES DAS \\ INFLUÊNCIAS DOS DIFERENTES VALORES DE PERFUSÃO SANGUÍNEA E DAS \\ CONSIDERAÇÕES DA TAXA DE PERFUSÃO SANGUÍNEA
}

\begin{abstract}
Fernanda Souza da SILVA"; Matheus Oliveira CASTRO²; Lucas Lanza BERNARDES³; Angélica Rodrigues de ARAÚJO ${ }^{4}$; Rudolf HUEBNER ${ }^{5}$

1. Mestre em Engenharia Mecânica e Discente de Doutorado do Programa de Pós Graduação em Engenharia Mecânica - PPGEMEC, Universidade Federal de Minas Gerais - UFMG, Belo Horizonte, MG, Brasil. nandasouzafisio@ yahoo.com.br; 2. Graduando em Engenharia Mecânica, Universidade Federal de Minas Gerais - UFMG, Belo Horizonte, MG, Brasil. matheus.castro112@gmail.com; 3. Mestre em Engenharia Mecânica pelo Programa de Pós Graduação em Engenharia Mecânica - PPGEMEC, Universidade Federal de Minas Gerais - UFMG, Belo Horizonte, MG, Brasil. lucas.lanzab@ hotmail.com; 4. Professora Doutora da Pontifícia Universidade Católica de Minas Gerais (PUCMinas), Belo Horizonte, MG, Brasil. angelica@bios.srv.br; 5. Professor Doutor da Universidade Federal de Minas Gerais - UFMG, Belo Horizonte, MG, Brasil. rudolf@ demec.ufmg.br
\end{abstract}

\begin{abstract}
This study aimed to simulate heat transfer in thermal equilibrium in the canine knee joint. We analyzed the impact of different values of blood perfusion available in the literature and considered blood perfusion rates. The geometric models of canine knee joints were created from a photographic record of a cross section of an anatomical part. Two geometric models were developed: one without the epidermis and one with the epidermis. A heat diffusion equation was used to model the heat transfer phenomenon. Numerical simulations of the canine knee in a thermal neutrality condition were performed using the ANSYS-CFX® program. The simulation results were compared with experimental in vivo data. The smaller percentage differences between the experimental and simulated in vivo results were found in simulations that used the blood flow rate as a function of temperature. The computer simulation proved to be a good alternative to evaluate the temperature of biological tissues.
\end{abstract}

KEYWORDS: Bio heat transfer. Pennes equation. Computational simulation. Thermal resource. Knee joint.

\section{INTRODUCTION}

Currently, thermal procedures have gained prominence in many healthcare applications, including the evaluation and prediction of thermal tissue damage (GASPERIN; JURICIC, 2009; GLUSKIN et al., 2005), use of hyperthermia for the treatment of cancer, cerebral hypothermia (VANLANDINGHAM; KURZ; WANG, 2015; KIRKMAN; SMITH, 2014), cryosurgery (SHI; CHEN; SHI, 2009) and therapeutic treatments to assist with rehabilitation (SILVA; FRANÇA; PINOTTI, 2011; TROBEC et al., 2008; ARAÚJO, 2009).

However, the success, safety and efficiency of treatments that involve heat transfer are highly dependent on an understanding of the thermal behavior in different biological tissues. Although in vivo determination of tissue temperature is employed for this purpose, there are still great difficulties and risks associated with carrying out these temperature monitoring measures, mainly due to the invasive nature, inaccuracy in the control of various parameters and the limitations of the measures (TROBEC et al., 2008).

Studies that investigated the temperature profiles of living tissues (SINGH; KUMAR, 2014; STROHER; STROHER, 2014; NARASIMHAN; JHA, 2012; NG; OOI, 2006) have continuously increased in number since 1948, which is when Harry Pennes proposed the first bioheat transfer model that related the temperature of biological tissues to blood perfusion and metabolic heat generation (PENNES, 1948). Since then, many alternative bioheat transfer models have been developed (MITCHELL; MYERS, 1968; KELLER; SEILER, 1971; WULF, 1974; CHEN; HOLMES, 1980; WEINBAUM; JIJI; LEMONS, 1984), providing a quantitative analysis of the complex heat transfer phenomena in living tissues.

Despite mathematical modeling being shown to be a reliable approach for the investigation of the temperature distribution inside living systems, analytical solutions are limited only to simplified 
problems with simple boundary conditions and no complex geometry (NG; TAN; OOI, 2009; MALISKA, 2004). In contrast, numerical simulations have few restrictions and can solve complex physical problems that also have complex geometries and general boundary conditions (MALISKA, 2004). For this reason, numerous studies have aimed to evaluate heat transfer in biological tissues computationally with numerical methods (PAUL et al., 2014; SILVA; FRANÇA; PINOTTI, 2011; TROBEC et al., 2008).

In the last two decades, the use of numerical simulations to solve complex health problems has become a reality due to the widespread use of computers and the relative ease of applications of numerical methods (MALISKA, 2004). Despite the many advantages of numerical simulations, it is known that the considerations included in computational problem solutions can strongly influence the results and generate an incorrect interpretation of the heat transfer process. In the studies found in the literature, boundary conditions and the adopted considerations may have no justification, and numerous simplifications may have been made (XIAO et al., 2011; XUE; HE; LIU, 2013). In addition, the results from the simulations are rarely compared with actual data (experimental in vivo), which leaves doubt about the veracity of the simulated data.

Thus, this study aimed to simulate heat transfer in thermal equilibrium in the canine knee joint and analyze the impact of different values of blood perfusion available in the literature as well as blood perfusion rates. The knee model was chosen because it is the largest and most requested complex joint of the body. It plays important roles in locomotion and posture maintenance, such as the transmission and support of loads, the retention time of the body and stability during travel (HIROKAWA, 2001). The knee joint is commonly affected by traumatic and/or degenerative lesions and, therefore, it is a joint that receives thermal interventions (therapeutic heating and cooling) most often (MARTIN et al., 2001; WARREN et al., 2004; LEVINE et al., 2008). In this context, our study performed simulations to serve as the basis for analysis in more complex systems, such as during transient heating and cooling.

\section{MATERIAL AND METHODS}

\section{Geometric model and mesh generation}

The geometric model of the canine knee joint was created based on a photographic record of a cross-section of an anatomical part (Figure 1a). Different tissues that make up the knee joint in canines were established by visual inspection. Subsequently, a geometric model was developed with the help of SolidWorks ${ }^{\circledR}$ software. For this study, two geometric models were developed: 1) considering the subcutaneous, adipose and muscle tissue, the pericapsular region and intraarticular cavity, excluding the epidermis layer, and 2) considering the epidermis layer and all tissues of geometric model 1 . The geometric models 1 and 2 were developed with a thickness of $0.5 \mathrm{~mm}$, and the model without the epidermis can be seen in Figure $1 b$.
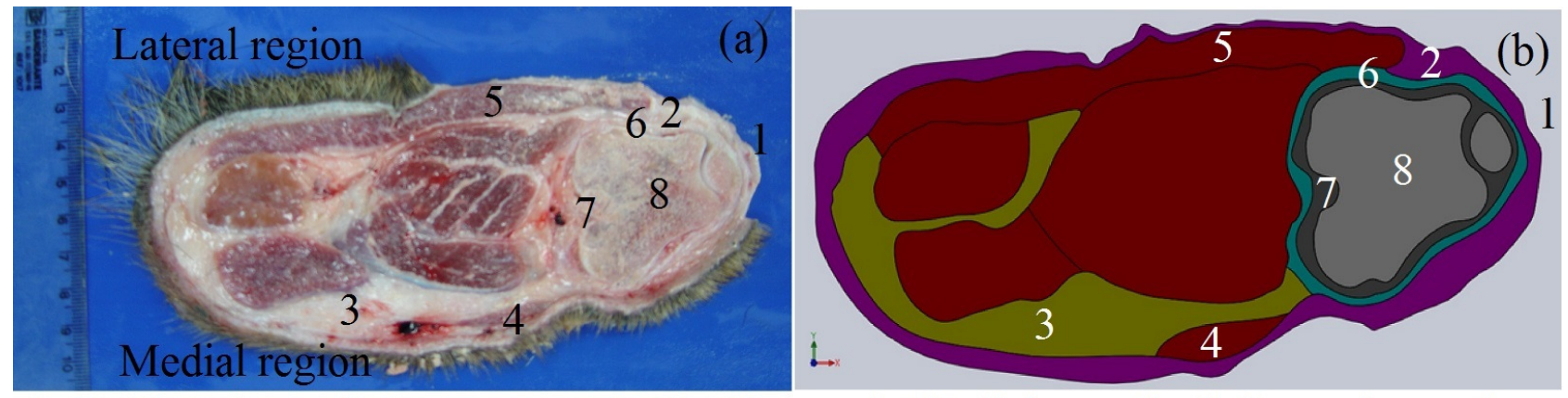

1- Epidermis; 2- Subcutaneous; 3- Fat tissue; 4- Medial muscle; 5- Lateral muscle; 6- Pericapsular region; 7- Cruciate ligaments; 8- Bone

Figure 1. (a) Cross section of the canine knee joint with the knee in full extension (Araújo, 2009) and (b) geometric model of the canine knee joint without the epidermis layer

After development of the computational domain, the meshes were built using ANSYS Meshing, a tool available in the Ansys Workbench (B) platform. According to the literature, meshing is one of the most critical aspects of simulation
(VERSTEEG; MALALASEKERA, 2007). A large or very small number of elements can result in extensive simulation times or inaccurate results, respectively (VERSTEEG; MALALASEKERA, 2007). The simulations were started with less 
refined mesh (mesh 1), and then the initial coarse meshes were gradually refined until the average changes in temperature in the tissues were lower than $1 \%$. Refinements followed the criteria of the length value of the mesh element (h) described by Celik et al. (2008). This parameter can be determined by Eq. (1):

$$
i n=\left[\frac{1}{N} \sum_{i=1}^{N}\left(\Delta V_{i}\right)\right]^{\frac{1}{g}}
$$

where $\Delta V_{i}$ is the mesh element volume and $N$ is the total number of the mesh elements.

Through the determination of $h$, it is possible to set the mesh refinement factor (r), determined by Eq. (2), which represents the ratio between the $h_{m_{g}}$ of a coarser mesh and the $h_{m r}$ of a subsequent refined mesh.

$r=\frac{h_{m q}}{h_{m r r}}$
SILVA, F. S. et al.

According to Celik et al., (2008), the mesh refinement factor should be greater than 1.3. Additionally, it is recommended that the value of $r$ is homogeneous among all meshes evaluated. These recommendations are based on experience, and they are still an object of study. For the ideal choice of mesh for each computational domain, the following were considered: 1) an independent solution from the mesh with a percentage lower than $1 \%$ difference between the results obtained using the previous coarse mesh and subsequent fine mesh and 2) at least a quality of $95 \%$ for the mesh elements. The obtained mesh parameters can be seen in Table 1. Among the three evaluated meshes, the intermediate one (mesh 2) met with the criteria considered for the geometric models 1 and 2 and, therefore, was chosen to perform the simulations. The meshes chosen for the simulations can be seen in Figures $2 \mathrm{a}$ and $2 \mathrm{~b}$, respectively. Both were composed mainly of quadrangular prisms, and the mesh of Figure 2a had tetrahedral elements in the bone and pericapsular regions.

Table 1. Parameters used for mesh refinement

\begin{tabular}{lllll}
\hline $\begin{array}{l}\text { Geometric } \\
\text { model }\end{array}$ & Mesh & h $(\mathbf{m m})$ & Element/Nodes & $\mathbf{R}$ \\
\hline 1 (Without & 1 & 1.42 & $1,738 / 4,532$ & 1.4 \\
epidermis) & 2 & 0.74 & $12,559 / 16,548$ & 1.4 \\
& 3 & 0.47 & $48,822 / 29,356$ & 1.4 \\
$2 \quad$ (With & 1 & 0.9 & $6,969 / 11,150$ & 1.4 \\
epidermis) & 2 & 0.56 & $29,002 / 68,442$ & 1.4 \\
& 3 & 0.33 & $97,517 / 18,7089$ & 1.4 \\
\hline
\end{tabular}

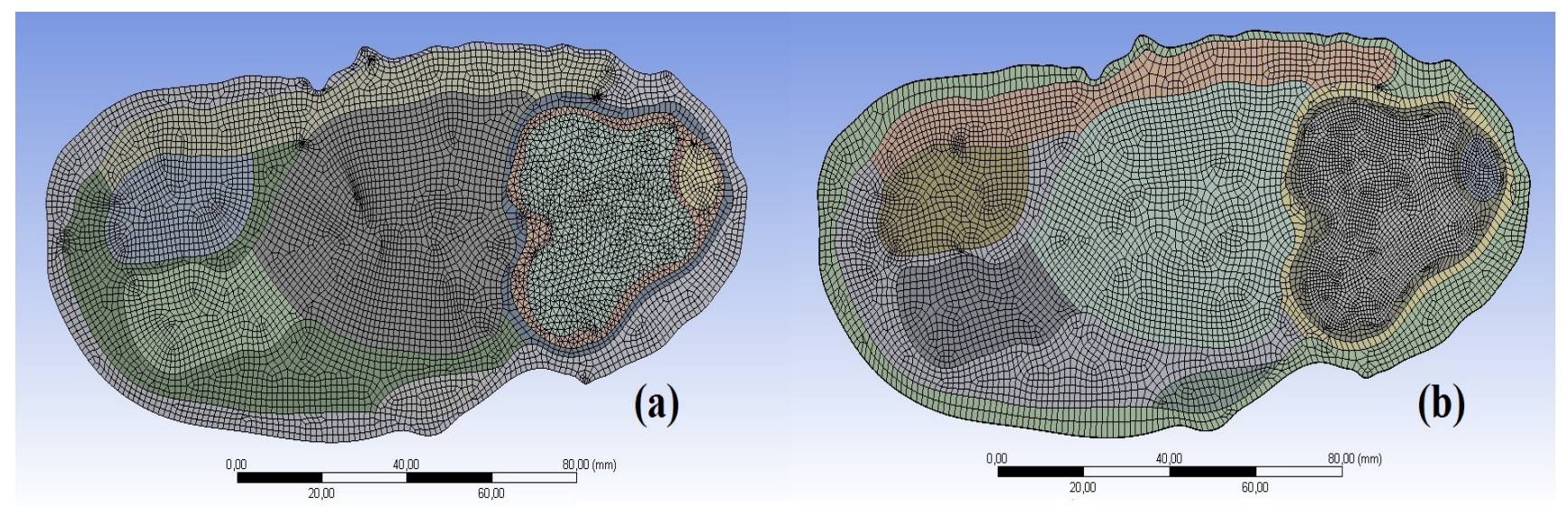

Figure 2. (a) Mesh 2 generated with the geometric model 1 and (b) mesh 2 generated with the geometric model 


\section{Mathematical model}

The partial differential equation for heat diffusion with second order terms of blood perfusion and metabolism will be used to model heat transfer by a conduction phenomenon in solid tissues during a state of thermal equilibrium. This equation can be described as:

$$
\begin{aligned}
& \frac{\partial}{\partial x}\left(k \frac{\partial T}{\partial x}\right)+\frac{\partial}{\partial y}\left(k \frac{\partial T}{\partial y}\right)+\frac{\partial}{\partial z}\left(k \frac{\partial T}{\partial z}\right)+\dot{q}_{m}^{\cdot}+\dot{q}_{w}=0 \text { (3) } \\
& q_{W}^{\prime}=w \rho_{s} c_{p s}\left(T_{r \theta f}-T_{t \theta g}\right)
\end{aligned}
$$

where $k$ is the thermal conductivity of each tissue $\left[\mathrm{Wm}^{-1 \circ} \mathrm{C}^{-1}\right] ; \boldsymbol{q}_{m}^{-}$is the metabolic heat rate $\left[\mathrm{Wm}^{-3}\right] ; q_{w}^{\prime}$ is the blood perfusion rate of the tissue $\left[\mathrm{Wm}^{-3}\right] ; \boldsymbol{w}$ is blood perfusion $\left[\mathrm{m}^{3} \mathrm{~s}^{-1} \mathrm{~m}^{-3}\right] ; \boldsymbol{\rho}_{s}$ corresponds to the blood specific mass $\left[\mathrm{kgm}^{-3}\right] ; c_{p s}$ is the specific heat of blood $\left[\mathrm{Jkg}^{-1}{ }^{\circ} \mathrm{C}^{-1}\right]$ and $\boldsymbol{T}_{\text {ref }}$ and $T_{t e c}$ are rectal and tissue temperatures, respectively.

Because the present study aimed to evaluate the effects of blood perfusion rate $\left(\dot{q}_{w}\right)$ in the tissues temperature distribution, the simulations were performed with different considerations of blood perfusion rates (constant or in function of temperature) (equation 3.4). The rectal temperature $T_{\text {ref }}\left(38.1^{\circ} \mathrm{C}\right)$ and the temperatures used as the initial condition of each tissue layer were taken from the Araújo (2009) study. According to the author, the initial temperatures were considered to be equal to the average of the experimental temperatures obtained in a thermal neutrality condition $\left(24.7^{\circ} \mathrm{C}\right)$. The bone initial temperature was based on the innermost region in which the temperature was measured in this study (cruciate ligaments region).

\section{Tissues properties}

The values of specific heat, density, thermal conductivity and metabolic heat adopted to perform the simulations were taken from the Araújo (2009) study and averages comprised the data published in the literature. The values of the variables used for each of the layers are shown in Table 2. All properties were considered constant for implementation of the simulations.

Table 2. Physiological properties and thermo-physical layers of tissues and blood.

\begin{tabular}{lcccc}
\hline Region & $\begin{array}{c}\mathrm{c}_{\mathrm{p}} \\
\left(\mathrm{Jkg}^{-10} \mathrm{C}^{-1}\right)\end{array}$ & $\begin{array}{c}\rho \\
\left(\mathrm{kgm}^{-3}\right)\end{array}$ & $\begin{array}{c}\mathrm{k} \\
\left(\mathrm{Wm}^{-10} \mathrm{C}^{-1}\right)\end{array}$ & $\begin{array}{c}\mathrm{q}_{\mathrm{m}} \\
\left(\mathrm{Wm}^{-3}\right)\end{array}$ \\
\hline Epidermis & 3,593 & 1,200 & $2.28 \times 10^{-1}$ & 0 \\
Subcutaneous & 3,365 & 1,200 & $4.64 \times 10^{-1}$ & 200 \\
Fat tissue & 2,678 & 937 & $2.03 \times 10^{-1}$ & 3.9 \\
Muscle & 3,684 & 1,097 & $5.29 \times 10^{-1}$ & 716 \\
Pericapsular & 3,500 & 1,051 & $4.98 \times 10^{-1}$ & 0 \\
Cruciate ligaments & 4,190 & 1,000 & $6.10 \times 10^{-1}$ & 0 \\
Bone & 1,785 & 1,585 & $7.35 \times 10^{-1}$ & 368.3 \\
Blood & 3,800 & 1,060 & - & - \\
\hline
\end{tabular}

It is known that the one of the greatest difficulties in obtaining accurate simulation results in living tissue comes from a lack of information and the reliability of blood perfusion values for the tissues. According to Barbanel and Cui (1990) and Barbanel and Cui (1991), among all physiological properties, blood perfusion is the most influential in the profile of tissue temperatures in thermal neutrality and in transient situations. Thus, in this study, the simulations were performed considering the blood perfusion values most commonly cited in the literature (LIU et al., 1999; TORVI; DALE, 1994; JIANG et al., 2002; GOWRISHANKAR et al., 2004; TZOU, 1992; FERREIRA; YANAGIHARA, 1999; WERNER; BUSE, 1988; COLLINS et al., 2004) for each of the tissues and the average values described by Araújo (2009). Among the modeled tissues, only the muscle and bone tissues showed different values for blood perfusion among the evaluated studies. Simulations were conducted by combining the two and four blood perfusion values found for muscle and bone, respectively, and using the average values described by Araújo (2009). Thus, nine simulations were performed. The blood perfusion values adopted to perform the simulations are listed in Table 3. 
Table 3. Combinations simulations of blood perfusion values for muscle and bone tissue.

\begin{tabular}{|c|c|c|c|c|c|c|}
\hline $\begin{array}{l}\text { Combinations } \\
\text { simulations }\end{array}$ & $\begin{array}{l}\text { W epidermis } \\
\left(\mathrm{m}^{3} \mathrm{~s}^{-1} \mathrm{~m}^{-3}\right. \\
\text { tissue })\end{array}$ & $\begin{array}{l}\text { W } \\
\text { subcutaneous } \\
\left(\mathrm{m}^{3} \mathrm{~s}^{-1} \mathrm{~m}^{-3}\right. \\
\text { tissue })\end{array}$ & $\begin{array}{l}\mathrm{w} \text { fat tissue } \\
\left(\mathrm{m}^{3} \mathrm{~s}^{-1} \mathrm{~m}^{-3}\right. \\
\text { tissue })\end{array}$ & $\begin{array}{l}\mathrm{w} \text { muscle } \\
\left(\mathrm{m}^{3} \mathrm{~s}^{-1} \mathrm{~m}^{-3}\right. \\
\text { tissue })\end{array}$ & $\begin{array}{l}\text { w pericapsular } \\
\left(\mathrm{m}^{3} \mathrm{~s}^{-1} \mathrm{~m}^{-3} \text { tissue }\right)\end{array}$ & $\begin{array}{l}\mathrm{w} \text { bone } \\
\left(\mathrm{m}^{3} \mathrm{~s}^{-1} \mathrm{~m}^{-3}\right. \\
\text { tissue })\end{array}$ \\
\hline $\mathrm{C} 1$ & 0 & $1.25 \times 10^{-3}$ & $8.6 \times 10^{-5}$ & $6.04 \times 10^{-4}$ & $1.8 \times 10^{-3}$ & $3.06 \times 10^{-4}$ \\
\hline $\mathrm{C} 2$ & 0 & $1.25 \times 10^{-3}$ & $8.6 \times 10^{-5}$ & $6.04 \times 10^{-4}$ & $1.8 \times 10^{-3}$ & $3.56 \times 10^{-4}$ \\
\hline $\mathrm{C} 3$ & 0 & $1.25 \times 10^{-3}$ & $8.6 \times 10^{-5}$ & $6.04 \times 10^{-4}$ & $1.8 \times 10^{-3}$ & $4.75 \times 10^{-4}$ \\
\hline $\mathrm{C} 4$ & 0 & $1.25 \times 10^{-3}$ & $8.6 \times 10^{-5}$ & $6.04 \times 10^{-4}$ & $1.8 \times 10^{-3}$ & $7.92 \times 10^{-4}$ \\
\hline $\mathrm{C} 5$ & 0 & $1.25 \times 10^{-3}$ & $8.6 \times 10^{-5}$ & $6.95 \times 10^{-4}$ & $1.8 \times 10^{-3}$ & $3.06 \times 10^{-4}$ \\
\hline C6 & 0 & $1.25 \times 10^{-3}$ & $8.6 \times 10^{-5}$ & $6.95 \times 10^{-4}$ & $1.8 \times 10^{-3}$ & $3.56 \times 10^{-4}$ \\
\hline $\mathrm{C} 7$ & 0 & $1.25 \times 10^{-3}$ & $8.6 \times 10^{-5}$ & $6.95 \times 10^{-4}$ & $1.8 \times 10^{-3}$ & $4.75 \times 10^{-4}$ \\
\hline $\mathrm{C} 8$ & 0 & $1.25 \times 10^{-3}$ & $8.6 \times 10^{-5}$ & $6.95 \times 10^{-4}$ & $1.8 \times 10^{-3}$ & $7.92 \times 10^{-4}$ \\
\hline $\begin{array}{l}\text { Average } \\
\text { values }\end{array}$ & 0 & $1.3 \times 10^{-3}$ & $2.9 \times 10^{-4}$ & $5.8 \times 10^{-4}$ & $1.8 \times 10^{-3}$ & $4.0 \times 10^{-4}$ \\
\hline
\end{tabular}

\section{Numerical simulation}

Simulations of temperature profiles in knee joints were performed in a steady state in a thermal neutrality condition. According to the literature, in the thermal neutral zone, the basal rate of thermogenesis is sufficient to neutralize the constant loss of body heat to the environment. Therefore, the core temperature remains stable without the need for activation of body thermoregulation mechanisms, which, by itself, would change the heat profile of the tissues.

To perform the simulation, a boundary condition of the second type at the upper and lower joint face was adopted, corresponding to a perfectly isolated or adiabatic surface. Thus, it was assured that the heat transfer occurred only in the twodimensional cross sectional plane of the canine knee, although the geometric model was three- dimensional. On the external surface of the geometric model, a boundary condition of third type was adopted that corresponded to the natural convection condition. To this end, an environmental temperature of $24.7^{\circ} \mathrm{C}$ (ARAÚJO, 2009) and a convective heat transfer coefficient (h) of $6 \mathrm{Wm}^{-2} \mathrm{~K}^{-1}$ (DEAR et al., 1997) were considered. Once the current model was composed of different tissues layers, it became necessary to define the interface condition between the various tissues. Thus, conservative heat flow between the tissue interfaces was assigned. Numerical simulations of the canine knee in a thermal neutrality condition were performed using ANSYS-CFX® software.

To achieve the objectives of the study, five simulations were performed. The considerations made in each simulation are listed in Table 4.

Table 4. Considerations adopted in the simulations with thermal neutrality (S1, S2, S3, S4 and S5)

\begin{tabular}{cccc}
\hline Simulations & Epidermis layer & Blood perfusion rate & Blood perfusion \\
\hline 1 & Absent & Constant & Average values \\
2 & Present & $\begin{array}{c}\text { Constant } \\
\text { Varying with } \\
\text { temperature }\end{array}$ & Average values \\
3 & Present & Constant & $\begin{array}{c}\text { Combinations of perfusion values } \\
\text { found in the literature } \\
\text { Combinations of perfusion values } \\
\text { found in the literature }\end{array}$ \\
\hline
\end{tabular}

The results of the simulation were evaluated and compared to average values of temperatures obtained from an experimental study in vivo (ARAÚJO, 2009). The average percentage difference between the simulation and experimental data was calculated for each of the tissue layers. A smaller or equal average percentage difference of $10 \%$ was considered acceptable.

\section{RESULTS AND DISCUSSION}

The results of numerical simulations were compared with the average of the temperatures measured by the thermocouples located in each tissue layer of the $10 \mathrm{dogs}$ participating in the experiment conducted by Araújo (2009). Exception is made to the bone tissue that did not have its temperature measured during the experiment. Therefore, the temperature of this region was 
considered equivalent to the cruciate ligaments one, as this is the closest tissue layer of the bone region.

The simulated temperatures presented were considered equal volumetric average of the considered tissue temperature. Thus, it was possible to assess whether the simulated temperature in a given tissue was within the random error range indicated by the standard deviation for that tissue and what was the percentage difference between experimental and simulated temperature values. A percentage difference equal to or less than $10 \%$ was regarded as satisfactory in this study.

\section{Simulations 1 and 2}

Table 5 presents the experimental temperatures measured in each tissue in thermal neutrality conditions along with the standard deviations for each tissue layer. It also summarizes the simulated temperature values of the geometric models 1 (without the epidermis layer) and 2 (with the epidermis layer), as well as the percentage differences between simulated and experimental temperatures for each tissue.

Table 5. Experimental temperatures, simulated temperatures and percentage differences between them for each tissue layer of the canine knee.

\begin{tabular}{|c|c|c|c|c|c|}
\hline Region & $\begin{array}{c}\text { Experimental } \\
\text { temperature }\left({ }^{\circ} \mathrm{C}\right)\end{array}$ & $\begin{array}{c}\text { Temperature } \\
\text { simulated } \\
\text { without the } \\
\text { epidermis }\left({ }^{\circ} \mathrm{C}\right)\end{array}$ & $\begin{array}{l}\text { Difference } \\
\text { of the } \\
\text { model } \\
\text { without the } \\
\text { epidermis } \\
(\%)\end{array}$ & $\begin{array}{l}\text { Temperature } \\
\text { simulated with } \\
\text { the epidermis } \\
\left({ }^{\circ} \mathrm{C}\right)\end{array}$ & $\begin{array}{l}\text { Difference } \\
\text { of the } \\
\text { model } \\
\text { without the } \\
\text { epidermis } \\
(\%)\end{array}$ \\
\hline Epidermis & $34.9 \pm 1.3$ & - & - & 36.9 & 6 \\
\hline Subcutaneous & $35.2 \pm 0.6$ & 37.1 & 5 & 37.1 & 5 \\
\hline Fat tissue & $36.2 \pm 0.5$ & 38.8 & 7 & 38.6 & 7 \\
\hline Lateral muscle & $36.5 \pm 0.9$ & 39 & 7 & 38.6 & 6 \\
\hline Medial muscle & $35 \pm 0.9$ & 38.4 & 10 & 38.1 & 9 \\
\hline Pericapsular & $35 \pm 0.6$ & 38.5 & 10 & 38.4 & 10 \\
\hline $\begin{array}{l}\text { Cruciate } \\
\text { ligaments }\end{array}$ & $37.1 \pm 1.0$ & 39.3 & 6 & 38.5 & 4 \\
\hline Bone & $37.1 \pm 1.0$ & 39.5 & 7 & 38.7 & 4 \\
\hline
\end{tabular}

Table 5 shows that slightly lower temperatures were obtained from the geometric model with the epidermis when compared to the geometric model without the epidermis. The greater temperature difference values occurred in the regions of cruciate ligaments and bone, in which the temperature variations were $0.8^{\circ} \mathrm{C}$. These temperature differences can be explained by the fact that the epidermal tissue is a natural insulator, so that its thermal conductivity value is low compared to other tissues that comprise the canine knee joint.

The model without the epidermis showed a greater percentage difference of $10 \%$ in the regions of the medial muscle and pericapsular, while the model with the epidermis showed the same value only for the pericapsular region. None of the tissues of either model had simulated temperatures within the standard deviation range of the experimental data.

Temperatures simulated in both models were always in the range of values higher than those measured experimentally. This overestimation of values can be explained by two rationales. The first refers to the fact that the values of thermo-physical and physiological properties of living tissues are not known very well yet because of the difficulty of measuring these values in experiments. Therefore, blood perfusion values, thermal conductivity, specific heat and the metabolism rate of each layer had some inherent uncertainty, which meant the overestimated values of these properties may generate simulated temperatures above the values measured in vivo. The second reason for the high temperature values found in this model is that it considers the blood perfusion rate as a constant. 
This is a hypothesis that does not accurately represent the mathematical model proposed by Pennes (1948) in a bioheat transfer equation in living tissue, which suggested that the blood flow rate is a function of the temperature difference between blood and tissue.

Based on the results of this first model, the geometric model 2 (with the epidermis) was adopted for the simulations carried out subsequently. Furthermore, the tissue blood perfusion started to be described as a function of temperature for each layer, thus seeking results based on hypotheses more consistent with the physical reality of the bioheat transfer process.

\section{Simulation 3}

Table 6 lists the experimental temperature values with standard deviations for each tissue, the simulated temperature values considering the blood perfusion rate varying with tissue temperature and the percentage difference between both.

Table 6. Experimental temperatures with standard deviations, simulated temperature values and percentage differences for each tissue.

\begin{tabular}{lccc}
\hline Regions & $\begin{array}{c}\text { Experimental temperature } \\
\left({ }^{\circ} \mathrm{C}\right)\end{array}$ & $\begin{array}{c}\text { Temperature } \\
\text { Simulation 2 }\end{array}$ & $\begin{array}{c}\text { Difference } \\
(\%)\end{array}$ \\
\hline Epidermis & $34.9 \pm 1.3$ & 36.2 & 4 \\
Subcutaneous & $35.2 \pm 0.6$ & 36.5 & 4 \\
Fat tissue & $36.2 \pm 0.5$ & 37.2 & 3 \\
Lateral muscle & $36.5 \pm 0.9$ & 37.1 & 2 \\
Medial muscle & $35 \pm 0.9$ & 36.7 & 5 \\
Pericapsular & $35 \pm 0.6$ & 37.3 & 7 \\
Cruciate ligaments & $37.1 \pm 1.0$ & 37.3 & 1 \\
Bone & $37.1 \pm 1.0$ & 37.5 & 2 \\
\hline
\end{tabular}

Table 6 allows comparison of the experimental data with the simulated data. It should be noted that the simulated temperature values were all higher than the experimental temperatures, as had occurred in simulation 1. However, it is clear that the percentage differences in values from simulation 2 were lower than those in simulation 1. The greatest percentage difference in simulation 1 was $10 \%$ in the medial muscle and pericapsular region, while in simulation 2 , it was $7 \%$ in the pericapsular region.

Evaluating the upper limits of experimental temperatures, which are given by the average of the experimental temperature of a tissue plus its respective standard deviation, it can be noted that the epidermis, lateral muscle, cruciate ligaments and bone showed simulated temperatures within the standard deviation range.

Therefore, simulation 2, which considers the blood perfusion rate varying with temperature, was able estimate more accurately the temperature distribution inside the canine knee joint because it showed the lowest percentage differences and simulated temperatures within the standard deviation range.

Table 7 shows comparisons of simulated temperature values obtained by the first simulation (with a constant blood perfusion rate) and simulation 2 values (with the blood perfusion rate as a function of the tissue temperature) with the temperature difference between them.

Table 7. Temperature values of simulations 1 and 2 and the temperature difference between them

\begin{tabular}{lccc}
\hline Region & Temperatures of Simulation 1 $\left({ }^{\circ} \mathrm{C}\right)$ & $\begin{array}{r}\text { Temperatures of Simulation 2 } \\
\left({ }^{\circ} \mathrm{C}\right)\end{array}$ & $\begin{array}{c}\text { Difference } \\
\left({ }^{\circ} \mathrm{C}\right)\end{array}$ \\
\hline Epidermis & 36.9 & 36.2 & 0.7 \\
Subcutaneous & 37.1 & 36.5 & 0.6 \\
Fat tissue & 38.6 & 37.2 & 1.4 \\
Lateral muscle & 38.6 & 37.1 & 1.5 \\
Medial muscle & 38.1 & 36.7 & 1.4 \\
Pericapsular & 38.4 & 37.3 & 1.1 \\
Cruciate ligaments & 38.5 & 37.3 & 1.2 \\
Bone & 38.7 & 37.5 & 1.2 \\
\hline
\end{tabular}


When evaluating the values of temperatures between the two simulations, it is clear how the simulation with blood perfusion rates as a function of the tissue temperature was able to produce low temperatures more consistent with the experimental data. The biggest temperature difference between simulations was $1.4^{\circ} \mathrm{C}$, which was between adipose tissue and the lateral muscle.

This temperature drop was because, in thermal neutrality, the blood reference temperature; i.e., $38.1^{\circ} \mathrm{C}$, was always higher than the temperature of the tissues. Therefore, the blood perfusion rate acted as a positive source giving heat to tissues and increasing their temperatures. As the blood perfusion rate is a function of the temperature difference between the blood, which has a constant temperature, and a tissue whose temperature is increasing, the temperature difference between blood and tissues tended to decrease. Thus, the blood perfusion rate of a tissue decreased and the heat transferred from blood to the tissues was less, thus leading to lower temperature values.

The cross section of the canine knee joint can be seen in Figure 3, which shows the temperature distribution resulting from simulation 2 .

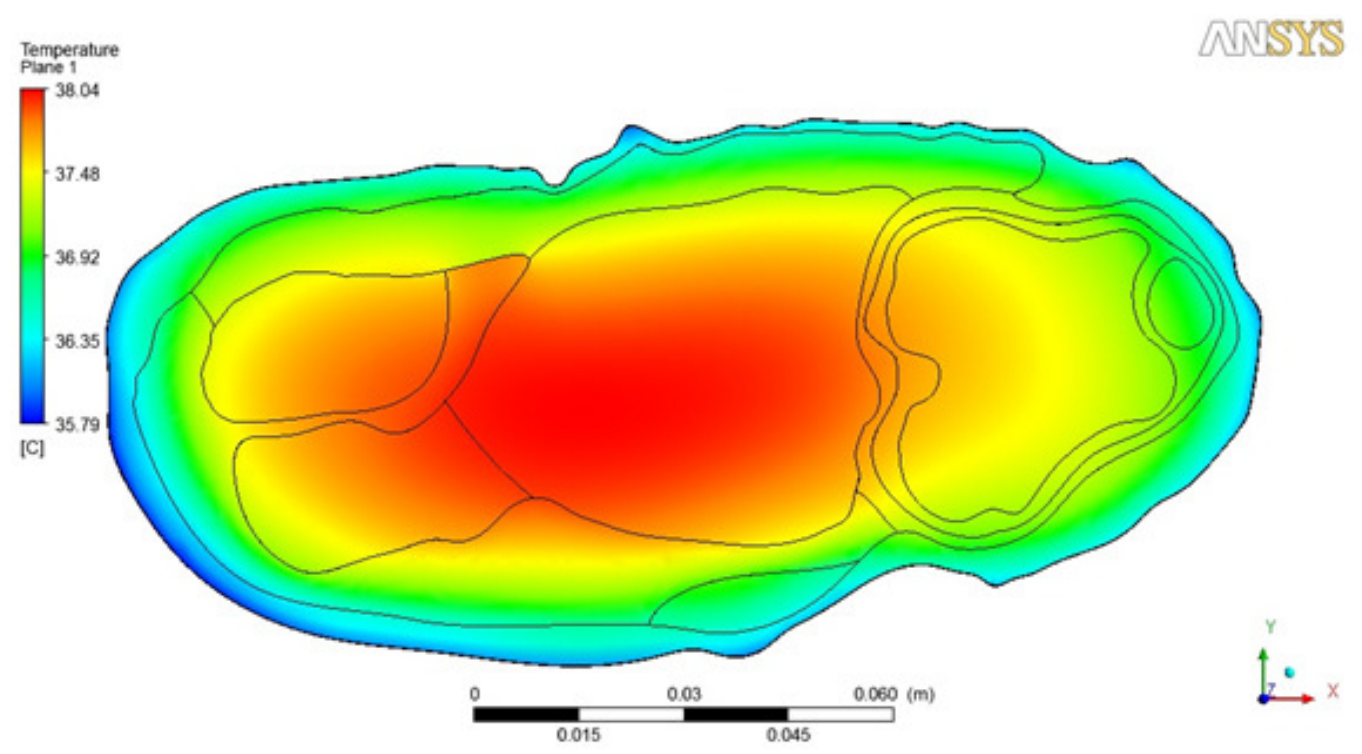

Figure 3. Temperature field obtained by simulation 2 in a cross section of the canine knee joint in a thermal neutrality condition.

Through a reading of the temperature distribution, it was noted that the external tissues, epidermis, subcutaneous, lateral muscle and fat, had lower temperatures because of the proximity to natural convection conditions imposed on the epidermis surface. As we evaluated the model more internally, it was seen that the temperature rises to the innermost regions, composed of muscle, the pericapsular region, cruciate ligaments and bone. Therefore, there was an increasing temperature gradient from the outermost layers to the innermost, which was expected due to the tendency of the organisms to regulate the core temperature to maintain a certain innermost region in higher temperature ranges.

Simulation 2 proved to more accurately and consistently model heat transfer in living tissues than simulation 1 because their temperature values were closer to the in vivo measurements. They had a lower percentage difference and simulated temperatures within the standard deviation range of the experimental data for some tissues. Therefore, as the only distinction between simulation 1 and simulation 2 was how the bioheat transfer equation of Pennes (1948) was applied to the model, as in simulation 1 , the blood perfusion rate term was considered constant. In simulation 2, it was considered a function of the temperature of the tissue. We noted the importance of presenting the rate of blood perfusion as a function of the tissue temperature.

In view of the importance of the blood perfusion rate for the model and because the temperature distribution was sensitive to this parameter, the importance of understanding this portion of the heat bioheat equation became clear. Therefore, the values used in blood perfusion that were considered an average were replaced by values found in the literature. These values were obtained by in vivo experiments carried out in several studies. Thus, simulations 4 and 5 were performed with combinations of blood perfusion values, making 
possible the evaluation of the temperature distribution profile in the canine knee joint.

\section{Simulation 4}

Figure 4 shows average experimental temperatures for 10 dogs and with their respective standard deviations, and the simulated temperature values considering the average blood perfusion values in the literature and combinations $\mathrm{C} 1, \mathrm{C} 2, \mathrm{C} 3$ and $\mathrm{C} 5$ of these values. These combinations were chosen because they had smaller percentage differences of up to $10 \%$ in all layers.

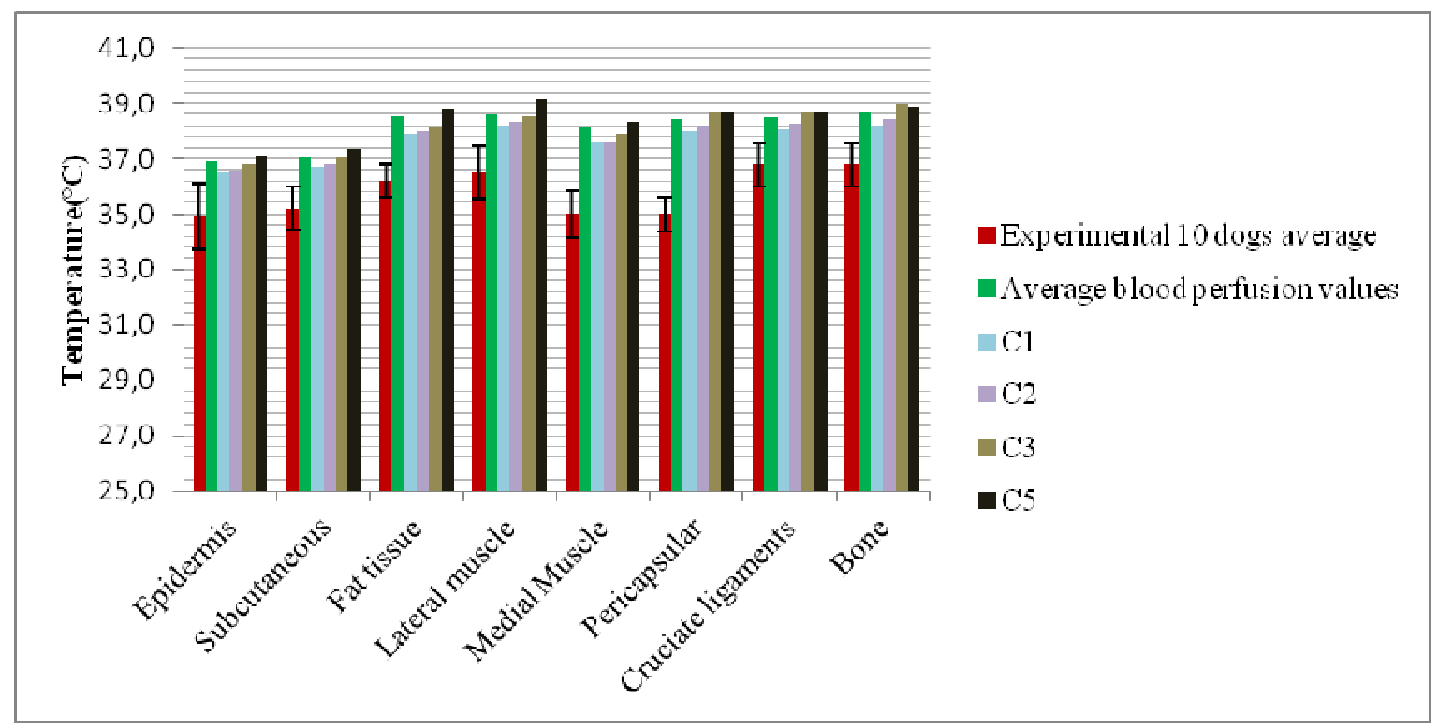

Figure 4. Experimental average temperature of $10 \mathrm{dogs}$ in thermal neutrality with their respective simulated standard deviations, temperatures with average values of perfusion and perfusion combinations.

The analysis in Figure 4 shows that all simulated temperatures and their respective standard deviations were higher than those measured experimentally. It can be seen that there was a clear distinction between the temperatures obtained for each combination, especially between $\mathrm{C} 1$ and $\mathrm{C} 5$ combinations because $\mathrm{C} 1$ tended to be lower and $\mathrm{C} 5$ had higher temperature values. This is because $\mathrm{C} 1$ had the lowest combined values of blood perfusion for bone and muscle tissues, whereas $\mathrm{C} 2$ and $\mathrm{C} 3 \mathrm{had}$ higher values in the bone region. The C5 combination had the highest temperatures in most of the tissues because it was carried out with a higher amount of blood perfusion in the muscular tissue, which is the tissue in the knee joint with a larger volume.

Given that in thermal neutrality, the blood reference temperature; i.e., $38.1^{\circ} \mathrm{C}$, was always above the tissue temperature, the blood perfusion rate always acted as a positive power source on the tissue, tending to increase its temperature. This fact was seen in the simulations because the combinations with higher perfusion values tended to have higher temperature values.
Table 8 presents the percentage difference between the experimental values of temperature and simulations for each tissue layer. The percentage differences for each of the eight simulated combinations and the simulation with mean perfusion values found in the literature are shown. Furthermore, the last line of the table corresponds to an average of the differences in each layer for each of the nine simulations.

Simulations with the average value of perfusion and the combinations $\mathrm{C} 1, \mathrm{C} 2, \mathrm{C} 3$ and $\mathrm{C} 5$ had a lower percentage difference of not more than $10 \%$ in all the studied tissues and were compatible with the criterion of physical validation adopted in this study. The temperature results of simulations considering the combination values $\mathrm{C} 1$ were the closest to the experimental data, with an average difference of $5 \%$. The $\mathrm{C} 8$ combination resulted in higher values for temperatures and a higher percentage difference with the experimental data; i.e., $16 \%$.

It is therefore possible to see how the blood perfusion of a tissue can influence the temperature field within the joint of a canine knee. 
Table 8. Values of the percent difference in temperature from each tissue for each of the nine simulations and the mean percentage difference found for each simulation.

\begin{tabular}{|c|c|c|c|c|c|c|c|c|c|}
\hline Layers & $\begin{array}{c}\text { Average } \\
(\%)\end{array}$ & $\mathrm{C} 1(\%)$ & $\mathrm{C} 2(\%)$ & $\mathrm{C} 3(\%)$ & $\mathrm{C} 4(\%)$ & C5 (\%) & C6 (\%) & C7 (\%) & $\mathrm{C} 8(\%)$ \\
\hline Epidermis & 6 & 5 & 5 & 6 & 7 & 6 & 7 & 7 & 9 \\
\hline Subcutaneous & 5 & 4 & 5 & 5 & 6 & 6 & 6 & 7 & 9 \\
\hline Fat tissue & 7 & 5 & 5 & 5 & 6 & 7 & 7 & 8 & 9 \\
\hline Lateral muscle & 6 & 5 & 5 & 6 & 7 & 7 & 7 & 8 & 10 \\
\hline Medial muscle & 9 & 7 & 8 & 8 & 10 & 10 & 10 & 10 & 12 \\
\hline Pericapsular & 10 & 9 & 9 & 10 & 14 & 10 & 11 & 12 & 16 \\
\hline $\begin{array}{l}\text { Cruciate } \\
\text { ligaments }\end{array}$ & 5 & 3 & 4 & 5 & 9 & 5 & 6 & 7 & 10 \\
\hline Bone & 5 & 4 & 4 & 6 & 10 & 6 & 6 & 8 & 11 \\
\hline Average & 6 & 5 & 6 & 6 & 9 & 7 & 8 & 8 & 11 \\
\hline
\end{tabular}

\section{Simulation 5}

This stage of the study included the realization of nine simulations of thermal neutrality conditions, and it differed from simulation 4 due to the blood perfusion rate being modeled as a function of the tissue temperature.
Figure 5 lists the experimental temperature values measured in thermal neutrality in 10 dogs along with their respective standard deviations, the temperature values simulated with the average blood perfusion values found in the literature and temperature values for combinations $\mathrm{C} 1, \mathrm{C} 2, \mathrm{C} 3$, and

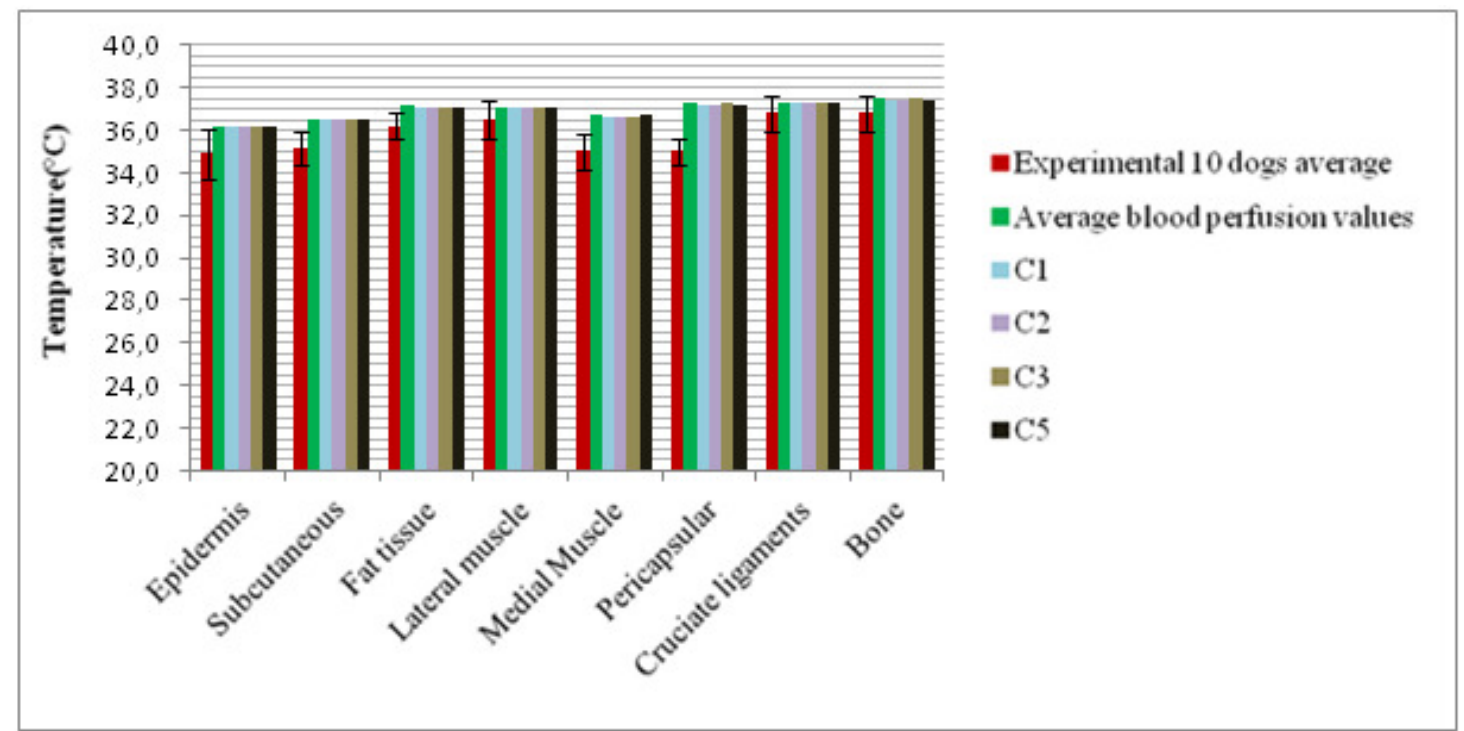

Figure 5. Experimental temperature average for $10 \mathrm{dogs}$ in thermal neutrality with their respective standard deviations, simulated temperatures with average values of perfusion and perfusion combinations.

Figure 5 shows that all simulated temperatures were higher than those measured experimentally. However, the lateral muscles and regions of the cruciate ligaments and bone presented temperature values within the standard deviation range. It is noted that the simulated temperature values showed no major differences; i.e., temperatures using combinations of blood perfusion values or the average of the data found in the literature were practically the same.
Table 9 shows better quantifications of these small differences between simulations. It shows the percentage difference between the experimental and simulated temperature values for each tissue layer. The percentage differences of each of the eight simulated combinations, and the simulation with mean perfusion values found in the literature are shown. Furthermore, the last line of the table corresponds to an average of the differences in each layer to each of the nine simulations. 
Table 9. Percentage difference of temperature values from each tissue for each of the nine simulations and the mean percentage difference found in each simulation.

\begin{tabular}{|c|c|c|c|c|c|c|c|c|c|}
\hline Layers & Average (\%) & C1 (\%) & $\mathrm{C} 2(\%)$ & C3 (\%) & C4 (\%) & C5 (\%) & C6 (\%) & C7 (\%) & C8 (\%) \\
\hline Epidermis & 4 & $\overline{4}$ & 4 & 4 & 4 & 4 & 4 & 4 & 4 \\
\hline Subcutaneous & 4 & 4 & 4 & 4 & 4 & 4 & 4 & 4 & 4 \\
\hline Fat tissue & 3 & 2 & 2 & 2 & 2 & 2 & 2 & 3 & 3 \\
\hline Lateral muscle & 2 & 1 & 1 & 1 & 2 & 2 & 2 & 2 & 2 \\
\hline Medial muscle & 5 & 5 & 5 & 5 & 5 & 5 & 5 & 5 & 5 \\
\hline Pericapsular & 7 & 6 & 6 & 6 & 7 & 6 & 6 & 6 & 7 \\
\hline Cruciate ligaments & 1 & 1 & 1 & 1 & 2 & 1 & 1 & 1 & 2 \\
\hline Bone & 2 & 2 & 2 & 2 & 2 & 2 & 2 & 2 & 2 \\
\hline Average & 3 & 3 & 3 & 3 & 3 & 3 & 3 & 3 & 3 \\
\hline
\end{tabular}

Evaluating Table 9, it can be noted that, for the same tissue, nearly equal percentage differences were found for all simulations, independent of the adopted perfusion values. The major difference between simulations was $1 \%$ for some layers.

This result should be evaluated with caution because it at first seems to indicate that the blood perfusion values were not very influential on the temperature distribution within the canine joint in a neutral regime, which is a fact that would run counter to the results of simulation 4. This fact occurred because the blood perfusion rate was being modeled as a function of the tissue temperature. Therefore, there was variation across simulations of blood perfusion in muscle and bone, but there were also variations in temperatures. As the temperature variation was larger and more influential than the perfusion, the results tended not to present a major distinction between them. This fact does not indicate that the blood perfusion had no effect on the temperature field, but the temperature variation in tissues was more influential than the variation in perfusion.

Thus, when considering the blood flow rate as a function of temperature, all combinations of perfusion values and the average blood perfusion values were considered satisfactory in this study because none had a higher percentage difference than $10 \%$.

Numerical simulations are presented as lowcost and non-invasive alternatives, and they enable calculation, analysis and displays of the temperature changes that occur with time, at any point of the therapeutic target. We performed computer simulations of thermal neutrality situations. The simulations were performed on a steady-state basis considering 1) a constant blood perfusion rate as a function of temperature and 2) different blood perfusion values found in the literature. The results in the simulations were compared with experimental data in vivo. In general, simulations that considered the blood flow rates dependent on the temperature obtained a better approximation to the in vivo experimental data. Changes in blood perfusion values of muscle and bone layers influenced the results of simulations that considered a constant blood flow rate. Thus, it can be concluded that simulation studies that considered the blood perfusion rate fixed may alter the results by choosing a perfusion value. In the simulations with the blood perfusion rate as a function of temperature, the changes in perfusion values did not impact the simulated results.

\section{ACKNOWLEDGEMENTS}

The authors gratefully acknowledge CAPES for the doctoral scholarship granted; FAPEMIG for the support in the project APQ -02059-14 and $\mathrm{PIBIC/CNPq}$ for the undergraduate research scholarship (120222 / 2014-0).

RESUMO: O presente trabalho visa simular a transferência de calor, em equilíbrio térmico, na articulação do joelho canino e analisar o impacto dos diferentes valores de perfusão sanguínea disponíveis na literatura e das considerações da taxa de perfusão sanguínea. Os modelos geométricos da articulação do joelho canino foram criados com base em um registro fotográfico de um corte transversal de uma peça anatômica. Foram desenvolvidos dois modelos geométricos: 1- sem epiderme e 2 - com epiderme. A equação de difusão de calor foi utilizada para modelar o fenômeno 
de transferência de calor. As simulações numéricas do joelho canino na condição de neutralidade térmica foram realizadas utilizando o programa ANSYS-CFX®. Os resultados da simulação foram comparados com os dados experimentais in vivo. As menores diferenças percentuais, entre o experimento in vivo e os resultados simulados, foram encontradas nas simulações que utilizaram a taxa de perfusão sanguínea em função da temperatura. A simulação computacional mostrou-se uma boa alternativa para avaliar a temperatura dos tecidos biológicos.

PALAVRAS CHAVE: Biotransferência de calor. Equação de Pennes. Simulação computacional. Recurso térmico. Articulação, joelho

\section{REFERENCES}

ARAÚJO, A. R. Formulação e validação de um modelo térmico para estimativa da temperatura intraarticular. Tese (doutorado em engenharia mecânica). Universidade Federal de Minas Gerais. Departamento de Engenharia Mecânica, 2009.

CELIK, I. B.; GHIA, U.; ROACHE, P. J.; FREITAS, C. J.; COLEMAN, H.; RAAD, P. E. Procedure for Estimation and Reporting of Uncertainty Due to Discretization in CFD Applications. Journal of Fluids Engineering, v. 130, p. 078001-1 - 078001-4, 2008.

CHEN, M. M.; HOLMES, K. R. Microvascular contributions in tissue heat transfer. Annals of the New York Academy of Sciences, v. 335, p. 137-150, 1980. http://dx.doi.org/10.1111/j.1749-6632.1980.tb50742.x

COLLINS, C. M.; SMITH, M. B.; TURNER, R. Model of local temperature changes in brain upon functional activation. Journal of Applied Physiology, v. 97, p. 2051-2055, 2004.

http://dx.doi.org/10.1152/japplphysiol.00626.2004

CUI, Z. F.; BARBENEL, C. J. The influence of model parameter values on the prediction of skin surface temperature: I. Resting and surface insulation. Physics in Medicine and Biology, v. 35, n. 12, p. 1683-1697, 1990. http://dx.doi.org/10.1088/0031-9155/35/12/007

CUI, Z. F.; BARBENEL, C. J. The influence of model parameter values on the prediction of skin surface temperature: II. Contact problems. Physics in Medicine and Biology, v. 36, n. 12, p. 1607-1620, 1991. http://dx.doi.org/10.1088/0031-9155/36/12/006

DEAR, R. J.; ARENS, E.; HUI, Z.; OGURO, M. Convective and radiative transfer coefficients for individual human body segments. International Journal of Biometeorology, v. 40, p. 141-156, 1997. http://dx.doi.org/10.1007/s004840050035

FERREIRA, M. S.; YANAGIHARA, J. I. Um modelo do sistema termorregulador do corpo humano: exposição a ambientes quentes. Revista Brasileira de Engenharia Biomédica, v. 15, n. 1-2, p. 87-96, 1999.

GASPERIN, M.; JURICIC, D. The uncertainty in burn prediction as a result of variable skin parameters: An experimental evaluation of burn-protective outfits. Burns, v. 35, p. 970-982, 2009.

http://dx.doi.org/10.1016/j.burns.2008.12.018

GLUSKIN, A. H.; RUDDLE, C. J.; ZINMAN, E. J. Thermal injury through intraradicular heat transfer using ultrasonic devices: precautions and practical preventive strategies. Journal of the American Dental Association (JADA), v. 136, n. 9, p. 1286-1293, 2005. http://dx.doi.org/10.14219/jada.archive.2005.0346

GOWRISHANKAR, T. R.; STEWART, D. A.; MARTIN, G. T.; WEAVER, J. C. Transport lattice models of heat transport in skin with spatially heterogeneous temperature-dependent perfusion. BioMedical Engineering OnLine, v. 3, n. 42, 2004. 
HIROKAWA, S.; AMAMOTO, K.; KAWADAC, T. Circumferential measurement and analysis of strain distribution in the human ACL usinga photoelastic coating method. Journal of Biomechanics, v. 34, p. 11351143, 2001. http://dx.doi.org/10.1016/S0021-9290(01)00078-1

JIANG, S. C.; MA, N.; LI, H. J.; ZHANG, X. X. Effects of thermal properties and geometrical dimensions on skin burn injuries. Burns, v. 28, p. 713-717, 2002. http://dx.doi.org/10.1016/S0305-4179(02)00104-3

KELLER, K. H.; SEILER, L. J. An analysis of peripheral heat transfer in man. Journal of Applied Physiology, v.30, n.5, p.779-786, 1971.

KIRKMAN, M. A.; SMITH, M. Therapeutic hypothermia and acute brain injury. Anaesthesia and Intensive Care Medicine, v. 15, n. 4, p.171-175, 2014. http://dx.doi.org/10.1016/j.mpaic.2014.01.021

LEVINE, D.; MILLIS, D. L.; MARCELLIN-LITTLE, D.; TAYLOR, R. Reabilitação e Fisioterapia na Pratica de Pequenos Animais. $1^{a}$ ed. Editora Rocca, São Paulo: S.P., 2008. 280p.

LIU, J; CHEN, X.; XU, L. X. New thermal wave aspects on burn evaluation of skin subjected to instantaneous heating. IEEE Transactions on Biomedical Engineering, v. 46, n. 4, p. 420-428, 1999.

http://dx.doi.org/10.1109/10.752939

MALISKA, C. R. Transferência de calor e mecânica dos fluidos computacional. $2^{\mathrm{a}}$ edição. Rio de Janeiro: LTC Editora, 2004.

MARTIN, S. S.; SPINDLER, K. P.; TARTER, J. W.; DETWILER, K.; PETERSEN, H. A. Cryotherapy: an effective modality for decreasing intraarticular temperature after knee arthroscopy. The American Journal of Sports Medicine, v. 29, n. 3, p. 288-291, 2001.

MITCHELL, J. M.; MYERS, G. E. An analytical model of the countercurrent heat exchange phenomena. Biophysical Journal, v. 8, p. 897-911, 1968. http://dx.doi.org/10.1016/S0006-3495(68)86527-0

NARASIMHAN, A.; JHA, K. K. Bio-heat transfer simulation of retinal laser irradiation. International Journal for Numerical Methods in Biomedical Engineering, v. 28, p. 547-559, 2012. http://dx.doi.org/10.1002/cnm.1489

NG, E.Y.K.; OOI, E.H. FEM simulation of the eye structure with bioheat analysis. Computer Methods and Programs in Biomedicine, v. 82, p. 268-276, 2006. http://dx.doi.org/10.1016/j.cmpb.2006.04.001

NG, E. Y. K.; TAN, H. M.; OOI, E. H. Boundary element method with bioheat equation for skin burn injury. Burns, v. 35, p. 987-997, 2009. http://dx.doi.org/10.1016/j.burns.2009.01.010

PAUL, A.; NARASIMHAN, A.; KAHLEN, F.; DAS, S. Temperature evolution in tissues embedded with large blood vessels during photo-thermal heating. Journal of Thermal Biology, v. 41, p. 77-87, 2014.

http://dx.doi.org/10.1016/j.jtherbio.2014.02.010

PENNES, H. H. Analysis of tissue and arterial blood temperatures in the resting human forearm. Journal of Applied Physiology, v. 1, n. 2, p. 93-122, 1948.

RUBINSKY, B. Heat transfer during cryopreservation by perfusion through the vascular system, Cryobiology, v. 24, p. 537-541, 1987. http://dx.doi.org/10.1016/0011-2240(87)90056-3

SILVA, F. S.; FRANÇA, A. S.; PINOTTI, M. One-dimensional simulation of heating and cooling of canine knee joints. In: $21^{\text {nd }}$ INTERNATIONAL CONGRESS OF MECHANICAL ENGINEERING, Natal. Anais do COBEM 2011. Rio de Janeiro: Associação Brasileira de Ciências Mecânicas, 2011. 
SHI, J.; CHEN, Z.; SHI, M. Simulation of heat transfer of biological tissue during cryosurgery based on vascular trees. Applied Thermal Engineering, v. 29, p. 1792-1798, 2009.

http://dx.doi.org/10.1016/j.applthermaleng.2008.08.014

SINGH, S.; KUMAR, S. Numerical study on triple layer skin tissue freezing using dual phase lag bio-heat model. International Journal of Thermal Sciences, v. 86, p. 12-20, 2014.

http://dx.doi.org/10.1016/j.ijthermalsci.2014.06.027

STROHER, G. R; STROHER, G. L. Numerical thermal analysis of skin tissue using parabolic and hyperbolic approaches. International Communications in Heat and Mass Transfer, v. 57, p. 193-199, 2014. http://dx.doi.org/10.1016/j.icheatmasstransfer.2014.07.026

TORVI, D. A.; DALE, J. D. A finite element model of skin subjected to a flash fire. Journal of Biomechanical Engineering, v. 116, p. 250-255, 1994. http://dx.doi.org/10.1115/1.2895727

TROBEC, R.; STERK, M.; ALMAWED, S.; VESELKO, M. Computer simulation of topical knee cooling. Computers in Biology and Medicine. v. 38, p. 1076-1083, 2008.

http://dx.doi.org/10.1016/j.compbiomed.2008.08.004

TZOU, D. Y. Experimental evidence for the temperature waves around a rapidly propagating crack tip. ASME Journal of Heat Transfer, v. 114, p. 1042-1045, 1992. http://dx.doi.org/10.1115/1.2911875

VANLANDINGHAM, S. C.; KURZ, M. C.; WANG, H. E. Thermodynamic aspects of therapeutic hypothermia. Resuscitation, v. 86, p. 67-73, 2015. http://dx.doi.org/10.1016/j.resuscitation.2014.09.028

VERSTEEG, H. K.; MALALASEKERA, W. An introduction to computational fluid dynamics -The finite volume method. Prentice Hall. Second Edition, 2007.

XIAO, J.; HE; Z.; YANG, Y.; CHEN, B.; DENG, Z.; LIU, J. Investigation on three-dimensional temperature field of human knee considering anatomical structure. International Journal of Heat and Mass Transfer, $v$. 54, p. 1851-1860, 2011. http://dx.doi.org/10.1016/j.ijheatmasstransfer.2010.11.057

XUE, X.; HE, Z. Z.; LIU, J. Computational study of thermal effects of large blood vessels in human knee joint. Computers in Biology and Medicine, v. 43, p. 63-72, 2013.

http://dx.doi.org/10.1016/j.compbiomed.2012.10.004

WARREN, T. A.; McCARTY, E. C.; RICHARDSON, A. L.; MICHENER, T.; SPINDLER, K. P. Intraarticular knee temperature changes: ice versus cryotherapy device. The American Journal of Sports Medicine. v. 32, n. 2, p. 441-445, 2004. http://dx.doi.org/10.1177/0363546503258864

WEINBAUM, S.; JIJI, L. M. A new simplified bioheat equation for the effect of blood flow on local average tissue temperature. ASME Journal of Biomechanical Engineering, v. 107, n. 2, p. 131-139, 1985. http://dx.doi.org/10.1115/1.3138533

WEINBAUM, S., JIJI, L., LEMONS, D. E. Theory and experiment for the effect of vascular microstructure on surface tissue heat transfer-part I: anatomical foundation and model conceptualization. Journal of Biomechanical Engineering, v. 106, p. 321-330, 1984. http://dx.doi.org/10.1115/1.3138501

WERNER, J.; BUSE, M. Temperature profiles with respect to inhomogeneity and geometry of the human body. Journal of Applied Physiology, v. 65. p. 1110-1118, 1988. 